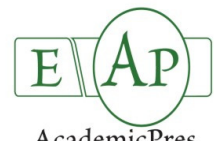

\title{
Effects of External Coloured Shade Nets on Sweet Peppers Cultivated in Walk-in Plastic Tunnels
}

\author{
Attila OMBÓDI ${ }^{1 *}$, Zoltán PÉK ${ }^{1}$, Péter SZUVANDZSIEV ${ }^{1}$, Zsuzsanna TÓTHNÉ \\ TASKOVICS ${ }^{2}$, Ambrus KÖHÁZI-KIS ${ }^{3}$, András KOVÁCS ${ }^{2}$, \\ Hajnalka LEDÓNÉ DARÁZSI ${ }^{4}$, Lajos HELYES ${ }^{1}$
}

\author{
'Szent István University, Faculty of Agricultural and Environmental Sciences, Institute of Horticulture, 1.Páter K. u, 2100, Gödöllo', Hungary;

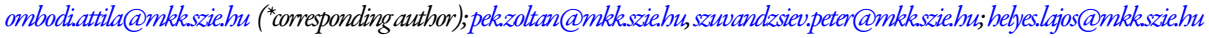 \\ ${ }^{2}$ Kecskemét College, Faculty of Horticulture,Department of Horticulture, 1-3.ErdeiF.tér, 6000, Keckkemét,Hungary; tothne.zsuzsanna@kfk.kefo.bu;koandi@t-online.hu \\ ${ }^{3}$ Keskemét College, FacultyofMechanical Engineering and Automation,10. Izsáki uit, 6000, Keskemét Hungary; kohazi-kis.ambrus@gamf.kefo.hu \\ 4DélKerTÉSz,3/B.Szarvasiutt,6600,Szentes,Hungary;ledone@delkertesz,bu
}

\begin{abstract}
Shading effect of external nets of different colours (white, green, yellow and red) on the yield of two "kapija" pepper (Capsicum anuum L.) cultivars was examined in walk-in plastic tunnels in Hungary under real cultivation circumstances. Shading nets decreased incoming radiation by $23-39 \%$ and reduced photosynthetically active radiation by $32-46 \%$. The highest retention was obtained by yellow and green nets, in the range of 450-550 nm and 550-670 nm, respectively. Relation was reported between the degree of shading and the average air temperature of the tunnels, however, treatments did not decrease tunnel air temperature significantly, compared to that of unshaded and paint-shaded control tunnels. This can be explained by the applied proper ventilation and mist irrigation. A strong and negative relation was noted between the intensity of shading and the relative chlorophyll content (SPAD value) of leaves. Shading net treatments did not increase yields, yellow and green nets even decreased it. Instead of tunnel air temperature, yield was mainly affected by photosynthetically active radiation in the experiment. Strong positive linear relation was declared between the chlorophyll content of the leaves and the yield. Results of the current research led to the conclusions that under Hungarian climatic conditions the use of shading nets was less justified if proper cooling techniques (ventilation and mist irrigation) were applied; even under the relatively high incident radiation experienced during the trials. In greenhouses of less favourable climatic conditions, red or white shading nets are recommended instead of commonly used green ones in Hungary.
\end{abstract}

Keywords: air temperature, photosynthetically active radiation, relative chlorophyll content, relative shading, solar radiation, yield

\section{Introduction}

Low-cost walk-in plastic tunnels are still very commonly used for vegetable - including pepper (Capsicum anuum L.) cultivation in East-Central Europe (FruitVeB, 2013). Overheating could be a serious problem in these tunnels considering high summer temperatures. To control air temperature generally ventilation, shading paint, external shading nets and/or mist irrigation are applied (López-Marín et al., 2012; Zhu et al., 2012).

In the Mediterranean area the use of screens to protect plants is a usual strategy in the horticulture (Legarrea et al., 2010). Sweet pepper is proved to be well-adaptable to shaded environment (Kitta et al., 2014b). Moderate shading (30-50\%) protected bell pepper from sunburns, reduced water use and resulted in high yields of good quality, however, more intensive shading reduced leaf photosynthesis and adversely affected productivity (DíazPérez, 2013; Shahak et al., 2008; Zhu et al., 2012). Shading rate even more than $20 \%$ was not recommended for sweet pepper production by Kitta et al. (2014a) under Mediterranean conditions. According to the literature photoselective shading nets of red, pearl and yellow colour markedly increased productivity, improved fruit quality of different cultivated vegetables and reduced the crop infestation by pests and diseases. The combined effects resulted in better crop yields and lower susceptibility to decay during post-harvest storage compared to traditional shading methods (Stamps, 2009; Shahak, 2014). Yellow coloured mesh shades increased open field pepper yield and quality compared to traditional black nets (Fallik et al., 2009), while both yellow and pearl coloured nets reduced the occurrence of Alternaria and improved post-harvest qualities of the product (Goren et al., 2011).

Received: 12 Mar 2015. Received in revised form: 18 Aug 2015. Accepted: 10 Sept 2015. Published online: 10 Dec 2015. 


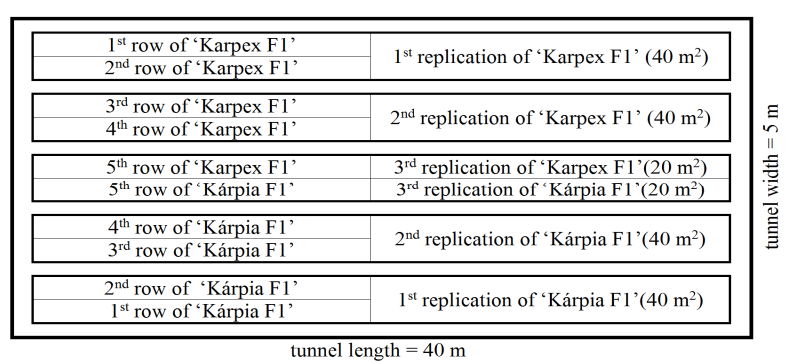

Fig. 1. Layout of the pepper rows and replications in the walkin tunnels

Although numerous studies focused on the use of shading nets in open field pepper cultivation, less result was obtained from the investigation on the effect of photoselective meshes on greenhouse sweet pepper production. In Almería, Spain, red nets of 30\% shading capacity resulted in higher yield in greenhouse pepper production than traditional whitewash (Shahak et al., 2004 cit. by Shahak et al., 2008). Red and pearl coloured internal shading nets improved tomato fruit quality and carotenoid content in walk-in plastic tunnels in Serbia (Ilic et al., 2012; Ilicet al., 2015).

The current study aimed to contribute to the knowledge on the effect of different coloured shading nets on the incident radiation and air temperature of walk-in tunnels and on the yield of pepper cultivated in the tunnels.

\section{Materials and Methods}

\section{Conditions and methods of the cultivation}

The experiment was established in the Southern Great Plain region of Hungary close to Lajosmizse (NL $47^{\circ} 00^{\prime}$, EL 19 $64^{\circ}$ ) in 2012 in a private vegetable farm. Cultivation experiments were settled in six unheated walk-in plastic tunnels of $2.3 \mathrm{~m}$ height, $5 \mathrm{~m}$ width and $40 \mathrm{~m}$ length. Tunnel ends were designed to be converted and two side vents in each tunnel provided proper ventilation. After sowing on the $15^{\text {th }}$ of March, seedlings were transplanted on the $24^{\text {th }}$ of April distributed in 5 twin rows in each tunnel ( 10 rows as a total for each tunnel) at a distance of $0.3 \mathrm{~m}$ and $0.7 \mathrm{~m}$ between the rows. The space between the plants in the row was $0.25 \mathrm{~m}$, resulting in a density of 8 plants per $\mathrm{m}^{2}$. Seedlings of 'Kárpia $\mathrm{F}_{1}$ ' pepper cultivar were planted on the five left rows and 'Karpex $F_{1}$ ' peppers on the five right rows, both cultivars of "kapija" type (Fig. 1).

As the general practice for Hungarian small-scale vegetable forcing farms, fertigation, ventilation and mist irrigation were operated manually. Fertigation was daily dosed through a drip irrigation system. Overhead micro spray irrigation was applied each day for 5 minutes when tunnel air temperature exceeded $30^{\circ} \mathrm{C}$. In the daytime the ends of the tunnels and the side vents were open when tunnel air temperature was over $22^{\circ} \mathrm{C}$. At night-time the side vents were continuously open when outside air time temperature exceeded $15^{\circ} \mathrm{C}$. Eight harvests were managed from $2^{\text {nd }}$ July to $27^{\text {h }}$ September collecting only ripened, hard, full-grown fruits of at least $75 \%$ red colouration.

\section{Treatments}

Tunnels were cladded by $180 \mu \mathrm{m}$ thick and $8.5 \mathrm{~m}$ wide Extra S-24 type (Solarker Ltd., Kecskemét, Hungary) light stable polyethylene film in its second cultivation season. Besides the five treatments, unshaded tunnel represented control. In the first treatment Shadefix shading paint (Royal Brinkman B.V.,'sGravenzande, Holland) was applied at two occasions during the season with a dose of $100 \mathrm{~kg} / \mathrm{ha}$. Four tunnels were covered with different coloured shade nets (white, green, yellow and red, each tunnel by one colour) of $34 \mathrm{~g} / \mathrm{m}^{2}$ weight and of $8.35 \mathrm{~m}$ width (Első Magyar Kenderfonó PLC, Szeged, Hungary) at the top of the polyethylene cover for the whole season.

\section{Measurements}

Measurements of the intensity of incident solar radiation and intensity and spectral distribution of photosynthetically active radiation (PAR) were performed four times during the growing season $\left(26^{\text {th }}\right.$ June, $17^{\text {th }}$ July, $16^{\text {th }}$ August and $26^{\text {th }}$ September) both inside and outside the tunnels. Measurements of three replicates of each treatment were carried out at midday under clear skies with LI-185B type radiometer (LI-COR Inc., Lincoln, Nebraska, USA). Radiation intensity ( $\mathrm{W} \mathrm{m}^{-2}$ ) was measured by LI-200 pyranometer sensor while photosynthetic photon flux density (PPFD) values $\left(\mu \mathrm{mol} \mathrm{m}^{-2} \mathrm{~s}^{-1}\right)$ were determined by LI-190 SB type quantum sensor. Relative shading (reduction in radiation) of each treatment was calculated by using the formula of Oren-Shamir $e t$ al. (2001): relative shading $=100^{*}(1-$ radiation inside/radiation outside the tunnels). Spectral distribution of the PAR was measured by HR2000+ High Resolution type spectroradiometer (Ocean Optics Inc., Dunedin, Florida, USA). Air temperature in the tunnels was determined by Voltcraft DL-120TH type thermometer (Conrad Electronic SE, Hirschau, Germany) at every 30 minutes from $27^{\text {th }}$ April to $27^{\text {th }}$ September. Three data loggers for each tunnel were situated in the centre of the tunnels above the three middle twin rows at the height of plant apex. Data loggers were protected from direct sunlight and irrigation and their situation was adjusted to plant height every second week.

Relative chlorophyll content of leaves was measured by Minolta SPAD 502 type chlorophyll meter (Konica Minolta Inc., Tokyo, Japan) eight times during the season. Measurements were carried out on young, fully developed, unshaded leaves. $3 \times 30$ measurements were made for each cultivar and each treatment at one occasion.

Harvest was divided among treatments and cultivars, collecting fruits from the edge-positioned twin rows, from the next inner twin rows and from the half of middle twin rows (Fig. 1.). Fruits were classified as marketable and non-marketable (undersized, sunscald, injured, etc.) categories.

\section{Statistical analysis}

Air temperature values were evaluated by one-way ANOVA, while PPFD and SPAD values were analysed by two-way ANOVA considering treatment and data collection date as factors. Yield of the whole season was analysed with two-way unrepeated ANOVA with the factors of treatment and position of the rows. Mean separations were performed using Fisher's protected least significant difference test at $\mathrm{P} \leq 0.05$. Linear regression analysis was used to reveal relations among different parameters using Microsoft Excel 2007 software (Microsoft Inc., Redmond, Washington, USA).

\section{Results and Discussion}

\section{Radiation}

Average intensity of incident radiation based on four measurement times was $743 \mathrm{~W} \mathrm{~m}^{-2}$, considered medium high with 
400

Table 1. Effect of shading methods on the intensity of incident solar radiation and on photosynthetically active radiation (PAR) based on the average of four measurement times

\begin{tabular}{|c|c|c|c|c|}
\hline \multirow{2}{*}{ Treatment } & \multicolumn{2}{|c|}{ Solar radiation } & \multicolumn{2}{|c|}{ PAR } \\
\hline & $\mathrm{W} \mathrm{m}^{-2}$ & Relative shading (\%) & $\mu \mathrm{mol} \mathrm{m}{ }^{-2} \mathrm{~s}^{-1}$ & Relative shading (\%) \\
\hline Open field & $743 \mathrm{a}^{*}$ & & $1588 \mathrm{a}$ & \\
\hline Control tunnel & $638 \mathrm{~b}$ & 14 & $1200 \mathrm{~b}$ & 17 \\
\hline Shading paint & $565 c$ & 24 & $1175 \mathrm{bc}$ & 26 \\
\hline White net & $548 \mathrm{~cd}$ & 26 & $1063 \mathrm{de}$ & 33 \\
\hline Green net & $453 \mathrm{e}$ & 39 & $863 \mathrm{f}$ & 46 \\
\hline Yellow net & $520 \mathrm{~d}$ & 30 & $988 \mathrm{e}$ & 38 \\
\hline Red net & $575 \mathrm{~cd}$ & 23 & $1088 \mathrm{~d}$ & 32 \\
\hline
\end{tabular}

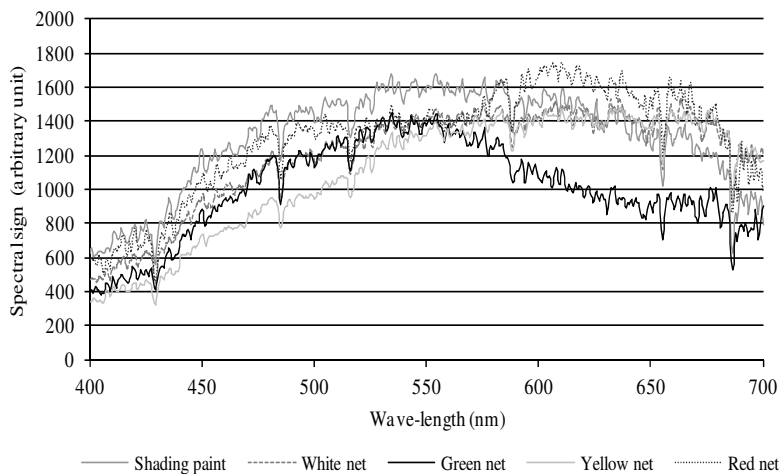

Fig. 2. Effects of the different shading treatments on spectral distribution in the PAR range on $18^{\text {th }}$ July

the highest value of $810 \mathrm{~W} \mathrm{~m}^{-2}$ measured on the $16^{\text {th }}$ of June. The polyethylene cover itself, used in its second season, decreased solar radiation by $14 \%$ and PAR by $17 \%$. Radiation was reduced the least by shading paint among the treatments (Table 1). Colour of the nets had a significant effect on shading capacity, green being responsible for the highest shading while red and white nets were the most permeable for radiation. In spite that weight and weave density of red and green nets were equal, a difference of $16 \%$ in shading effect was measured, affirming the findings of Ilic et al. (2015) where different incident radiation and PAR were measured in the case of nets of equal nominal shading capacity but different colour. Nets increased relative shading in the PAR range more (+ 7-9\%), than polyethylene alone and shading paint $(+2-$ $3 \%$ ) compared to relative shading measured in total solar radiation (Table 1). This finding is in harmony with the result of $9-11 \%$ increase, calculated from the data of Ilic et al. (2015).

Spectral measurements revealed differences in the penetration of radiation in case of different coloured nets, confirming previous results (Arthurs et al., 2013; Legarrea et al., 2010). Compared to shading paint, white coloured and red coloured nets, measured spectral signs for yellow and green nets were considerably lower in the 450-550 $\mathrm{nm}$ range and 550-670 $\mathrm{nm}$ range, respectively (Fig. 2). These results could explain the higher shading capacity of yellow and green nets.

\section{Airtemperature}

Average air temperature of tunnels fell in the optimal $21-23^{\circ} \mathrm{C}$ range of pepper cultivation (Wien, 1997) except in the case of the treatment with the yellow net. Shading did not affect considerably average air temperature in the season except in the case of yellow net where temperature was significantly higher than of other

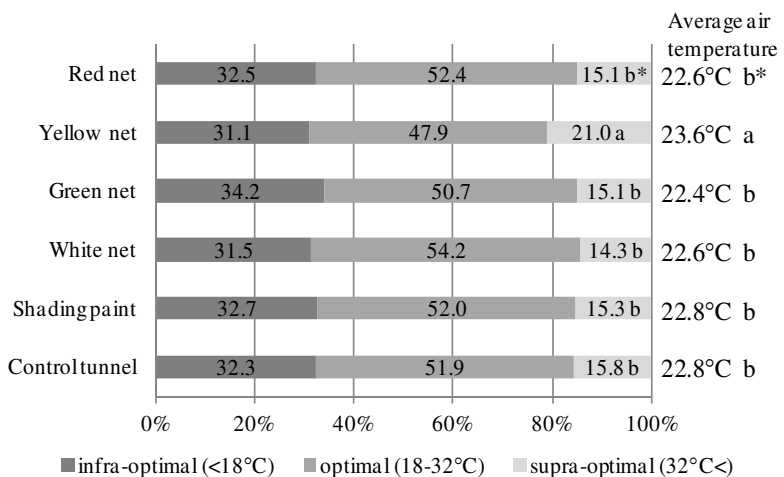

Fig. 3. Average air temperature of the tunnels and the distribution of infra-optimal, optimal and supra-optimal air temperature values for sweet pepper under different shading methods

*Mean separation within parameters by Fisher's protected least significant difference test at $\mathrm{P}<0.05$

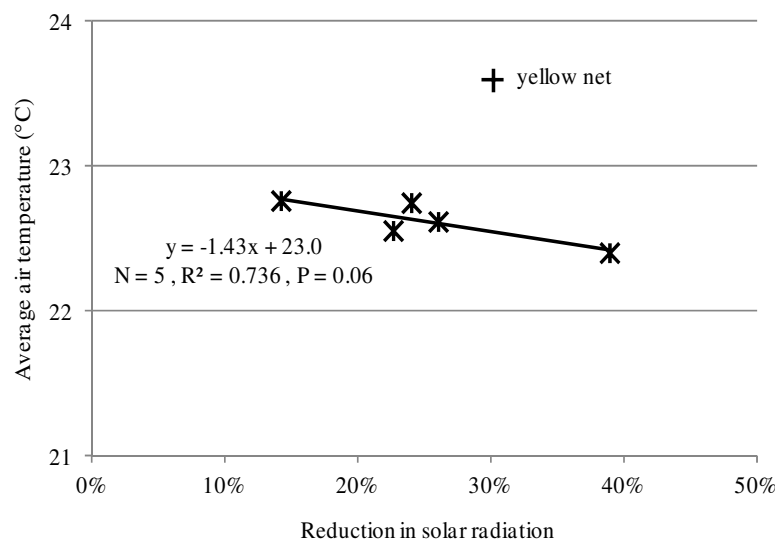

Fig. 4. Relation between reduction in solar radiation caused by the applied treatment and the average air temperature of the plastic tunnel

treatments (Fig. 3). In the yellow net treatment rate of optimal values $\left(18-32^{\circ} \mathrm{C}\right.$; Bosland and Votava, 1997) was lower (although not significantly) and rate of supra-optimal temperatures was significantly higher than those of other treatments. These results indicated that temperature conditions of yellow net treatment were less favourable and other treatments had no considerable difference in this pattern. 
Table 2. Effect of shading methods on the total yield and marketable yield ratio of two kapija type sweet pepper cultivars grown in plastic tunnels

\begin{tabular}{|c|c|c|c|c|}
\hline \multirow[b]{2}{*}{ Treatment } & \multicolumn{2}{|c|}{ 'Kárpia $F_{1}$ ' } & \multicolumn{2}{|c|}{ 'Karpex $F_{1} '$} \\
\hline & $\begin{array}{c}\text { Total yield } \\
\left(\mathrm{kg} \mathrm{m}^{-2}\right)\end{array}$ & $\begin{array}{l}\text { Ratio of marketable yield } \\
(\%)\end{array}$ & $\begin{array}{c}\text { Total yield } \\
\left(\mathrm{kg} \mathrm{m}^{-2}\right)\end{array}$ & $\begin{array}{l}\text { Ratio of marketable yield } \\
(\%)\end{array}$ \\
\hline Control tunnel & $7.07 \mathrm{a}^{*}$ & 81.4 & $8.08 \mathrm{a}$ & 81.3 \\
\hline Shading paint & $6.95 \mathrm{ab}$ & 82.7 & $7.38 \mathrm{ab}$ & 84.4 \\
\hline White net & $6.49 \mathrm{ab}$ & 82.0 & $7.65 \mathrm{a}$ & 81.3 \\
\hline Green net & $6.27 b c$ & 84.6 & $6.14 \mathrm{c}$ & 83.5 \\
\hline Yellow net & $5.69 c$ & 81.3 & $6.55 \mathrm{bc}$ & 84.5 \\
\hline Red net & $7.13 \mathrm{a}$ & 82.3 & $8.21 \mathrm{a}$ & 83.1 \\
\hline
\end{tabular}

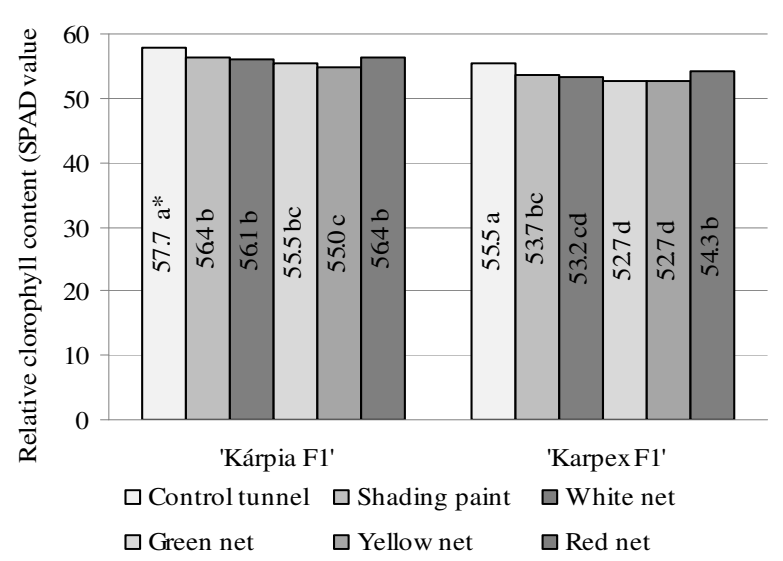

Fig. 5. Effect of shading methods on relative chlorophyll content of sweet pepper leaves

${ }^{*}$ Mean separation within cultivars by Fisher's protected least significant difference test at $\mathrm{P}<0.05$

Reduction of radiation by shading nets affect air temperature (Díaz-Pérez, 2013; Stamps, 2009) by strong negative relation, confirmed by the current research except in the case of yellow shading net (Fig. 4).

However, differences among colours of shading nets did not result in considerable air temperature variation (Fig. 3.), due to proper ventilation and regular misting. Hence, high temperatures of the yellow shading net treatment could not be explained solely by shading intensity. Unfortunately, based on the measured data we could not explain the unexpectedly high air temperature caused by the yellow shade net. Location of the tunnel, state of mist irrigation and vents were checked, and they were clearly not modifying factors.

\section{Relative chlorophyll content}

Based on the average of eight measurements, shading had a significant effect on leaf relative chlorophyll content (SPAD) in both cultivars (Fig. 5). Although all treatments reduced SPAD values, shading paint, white and red nets were responsible for lower, while yellow and green nets for higher reduction. Shading rate and $S P A D$ values resulted in a strong negative relation in both cultivars (Fig. 6). Higher shading reduced SPAD values, in contrast with the findings of López-Marín et al. (2012) and Zhu et al. (2012) where 60\% and 30\% shading intensity resulted in the highest SPAD values, respectively. However, our finding harmonizes with those reported by Legarrea et al. (2010) and Jang et al. (2014) noting that higher PAR resulted in higher SPAD values and higher chlorophyll concentration.

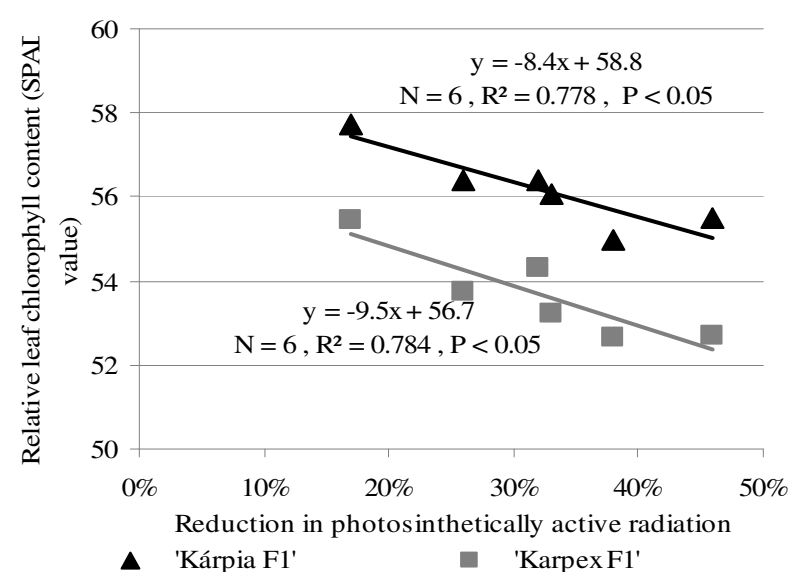

Fig. 6. Relation between shading intensity of the different treatments and average relative leaf chlorophyll content of sweet pepper leaves cultivated in walk-in plastic tunnels

\section{Yield}

Yield was not significantly increased by different shading treatments (Table 2). Similar to several previous open field research, red shade net provided good results (Stamps, 2009; Shahak, 2014), having the highest yield, although not significantly higher than those of control, shading paint or white coloured net shading. The lowest yields were recorded in the case of green and yellow nets, being significantly lower than that of control or red net treatments. This result can be explained with a lower penetration capacity of blue and red range radiation causing reduced photosynthetic activity.

Treatments did not affect the rate of marketable fruits significantly (Table 2). Sunscald did not occur more frequently in the control, unshaded tunnel (which itself also had a 14\% shading capacity), in contrast with earlier open field researches (Shahak et al., 2008; Shahak, 2014).

Results indicated that with the increase of shading intensity, yields decreased considerably, being significant in the case of 'Karpex F' cultivar (Fig. 7). Shahak et al. (2008) reported yield increase due to modification of radiation components solely by different coloured shading nets under open field circumstances. Rylski and Spigelman (1986) noted that when temperature and water availability were optimal, pepper yield was positively affected by light intensity. According to Díaz-Pérez (2014) optimal shading intensity could be reached by reducing the infrared range in order to maximize cooling effect and, in the meantime, minimize the decrease in PAR, thus, photosynthetic activity. Zhu et al. (2012) reported that effect of shading on pepper yield and quality was 
402

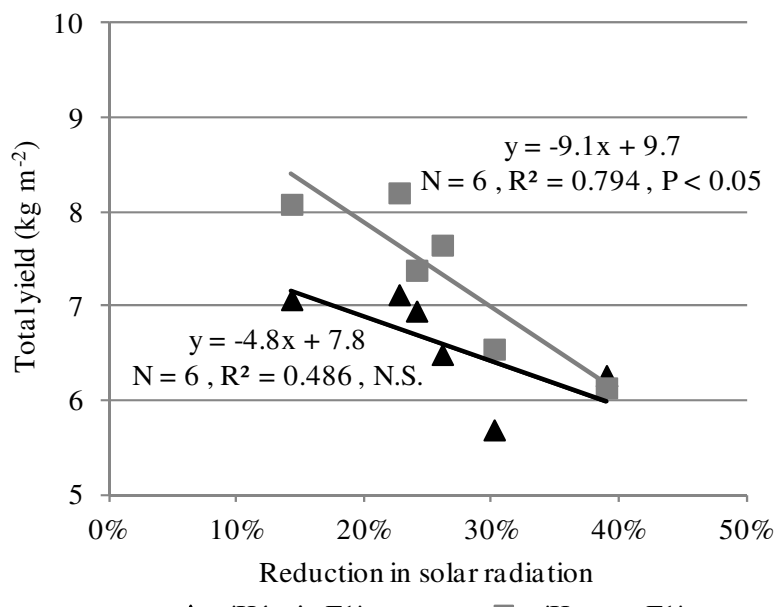

$\Delta$ 'Kárpia F1'

- 'Karpex F1'

Fig. 7. Relation between reduction in solar radiation and total yield of two kapija type sweet pepper cultivars grown in walkin plastic tunnels

highly dependent on geographic area and cultivation technology.

In the current research control treatment also provided optimal temperatures (Fig. 3), hence decrease of radiation and hereby temperature did not improve yield. Therefore, PAR intensity and photosynthetic activity were declared as limiting factors. Madeira et al. (2003) found strong, positive relation between SPAD value and chlorophyll content of pepper leaves. Hence, lower SPAD values indicate lower chlorophyll concentration and hereby reduced potential photosynthetic activity. This finding was confirmed by the significant strong positive relation between leaf SPAD values and yield in both cultivars included in the experiment (Fig. 8). In contrast with our findings Zhu et al. (2012) did not find significant correlation between SPAD values and yield, but they reported linear positive relation between net photosynthetic rates and fruit yield.

\section{Conclusions}

Shading net colours affected considerably the intensity and spectra of incident radiation. Nevertheless, applied shading methods did not affect positively the yield of the two examined pepper cultivars compared to those of the unshaded tunnel. Therefore, it can be concluded that when temperature of the tunnels can be maintained within optimal circumstances by proper ventilation and misting, shading can be considered unnecessary under Hungarian climatic conditions, even in the case of relatively high radiation as recorded in the research. Additionally, yellow and green shading nets reduced PAR to such an extent (38-46\%), which even decreased fruit yield. Hungarian pepper producers generally use green nets to shade plastic tunnels which should be avoided based on our research experience.

\section{Acknowledgments}

This work was partly supported by Research Centre of Excellence 9878-3/2015/FEKUT Szent István University, and KTIA_AIK_12-1-2012-0012 projects.

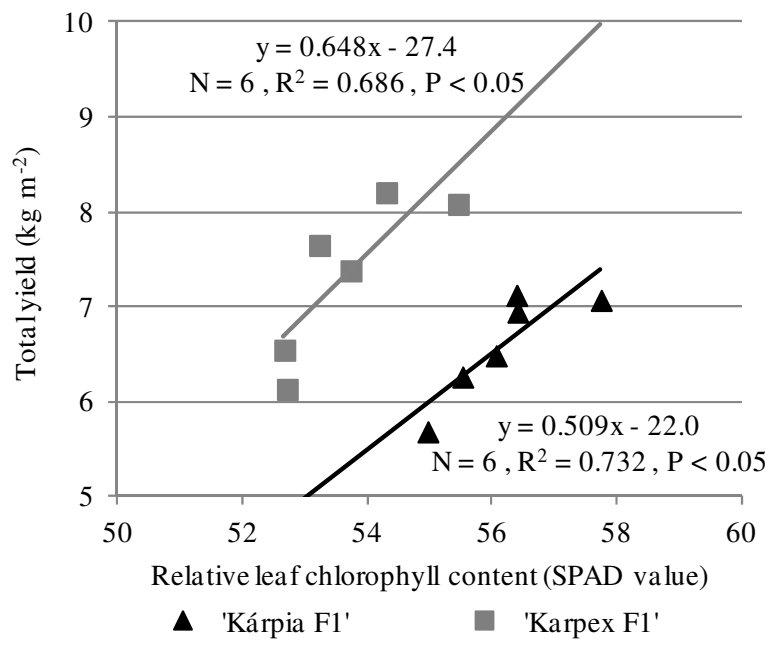

Fig. 8. Relation between relative leaf chlorophyll content and total yield of two kapija type sweet pepper cultivars grown in walk-in plastic tunnels

\section{References}

Arthurs SP, Stamps RH, Giglia FF (2013). Environmental modification inside photoselective shadehouses. HortScience 48:975-979.

Bosland PW, Votava E (1999). Peppers: vegetable and spice capsicums. CAB International, Wallingford, UK.

Díaz-PérezJC (2013). Bell pepper (Capsicum annuum L.) crop as affected by shade level: microenvironment, plant growth, leaf gas exchange, and leaf mineral nutrient concentration. HortScience 48:175-182.

Díaz-Pérez JC (2014). Bell pepper (Capsicum annum L.) crop as affected by shade level: Fruit yield, quality, and postharvest attributes, and incidence of phytophthora blight (caused by Phytophtora capsici Leon.). HortScience 49:891-900.

Fallik E, Alkalai-Tuvia S, Parselan Y, Aharon Z, Elmann A, Offir Y, Matan E, Yehezkel H, Ratner K, Zur N, Shahak Y (2009). Can colored shade nets maintain sweet pepper quality during storage and marketing? Acta Horticulturae 830:37-44.

FruitVeB (2013). Annual report of Hungarian fruit and vegetable sector. FruitVeB Hungarian Interprofessional Organisation for Fruit and Vegetables, Budapest (in Hungarian).

Goren A, Alkalai-Tuvia S, Perzelan Y, Fallik E, Aharon Z (2011). Photoselective shade nets reduce postharvest decay development in pepper fruits. Advances in Horticultural Science 25:26-31.

Ilic ZS, Milenkovic L, Stanojevic L, Cvetkovic D, Fallik E (2012). Effects of the modification of light intensity by color shade nets on yield and quality of tomato fruits. Scientia Horticulturae 139:90-95.

Ilic ZS, Milenkovic L, Šunić L, Cvetkovic D, Fallik E (2015). Effect of coloured shade-nets on plant leaf parameters and tomato fruit quality. Journal of the Science of Food and Agriculture 95:2660-2667.

Jang Y, Mun B, Do K, Um Y, Chun C (2014). Effects of photosynthetic photon flux and carbon dioxide concentration on the photosynthesis and growth of grafted pepper transplants during healing and acclimatization. Horticulture Environment and Biotechnology 55:387396. 
Kitta E, Baille AD, Katsoulas N, Rigakis N, González-Real MM (2014a). Effects of cover optical properties on screenhouse radiative environment and sweet pepper productivity. Biosystems Engineering 122:115-126.

Kitta E, Katsoulas N, Kandila A, González-Real MM, Baille A (2014b). Photosynthetic acclimation of sweet pepper plants to screenhouse conditions. HortScience 49:166-172.

Legarrea S, Karnieli A, Fereres A, Weintraub PG (2010). Comparison of UV-absorbing nets in pepper crops: spectral properties, effects on plants and pest control. Photochemistry and Photobiology 86:324330.

López-Marín J, Gálvez A, González A, Egea-Gilabert C, Fernández J (2012). Effect of shade on yield, quality and photosynthesis-related parameters of sweet pepper plants. Acta Horticulturae 956:545-552.

Madeira AC, Ferreira A, Varennes A, Vieira MI (2003). SPAD meter versus tristimulus colorimeter to estimate chlorophyll content and leaf colour in sweet pepper. Communication in Soil Science and Plant Analysis 34:2461-2470.

Oren-Shamir M, Gussakovsky EE, Shpiegel E, Nissim-Levi A, Ratner K, Ovadia R, Giller YE, Shahak Y (2001). Coloured shade nets can improve the yield and quality of green decorative branches of Pittosporum variegatum. Journal of Horticultural Science and Biotechnology 76:353-361.
Rylski I, Spigelman M (1986). Effect of shading on plant development, yield and fruit quality of sweet pepper grown under conditions of high temperature and radiation. Scientia Horticulturae 29:31-35.

Shahak Y, Gal E, Offir Y, Ben-Yakir D (2008). Photoselective shade netting integrated with greenhouse technologies for improved performance of vegetable and ornamental crops. Acta Horticulturae 797:75-80.

Shahak Y (2014). Photoselective netting: An overview of the concept, R \& $\mathrm{D}$ and practical implementation in agriculture. Acta Horticulturae 1015:155-162.

Stamps RH (2009). Use of colored shade nettings in horticulture. HortScience 44:239-241.

Wien HC (1997). Peppers. In: Wien HC (Ed). The physiology of vegetable crops. CAB International, Wallingford, UKpp 259-293.

Zhu JJ, Peng Q, Liang YL, Wu X, Hao WL (2012). Leaf gas exchange, chlorophyll fluorescence, and fruit yield in hot pepper (Capsicum anmuum L.) grown under different shade and soil moisture during the fruit growth stage. Journal of Integrative Agriculture 11:927-937. 